Published in final edited form as:

Planta Med. 2015 August ; 81(0): 1133-1140. doi:10.1055/s-0035-1546118.

\title{
New Bioactive Lupane Triterpene Coumaroyl Esters Isolated from Buxus cochinchinensis
}

\author{
Li Pan ${ }^{1}$, Ulyana Muñoz Acuña ${ }^{2}$, Heebyung Chai ${ }^{1}$, Hyun-Young Park ${ }^{1}$, Tran Ngoc Ninh ${ }^{3}$, Bui \\ Van Thanh $^{3}$, Emilio F. Merino ${ }^{4}$, Maria B. Cassera ${ }^{4}$, L. Harinantenaina Rakotondraibe ${ }^{1}$, \\ Esperanza J. Carcache de Blanco ${ }^{1,2}$, Djaja D. Soejarto ${ }^{5,6}$, and A. Douglas Kinghorn ${ }^{1}$ \\ ${ }^{1}$ Division of Medicinal Chemistry and Pharmacognosy, College of Pharmacy, The Ohio State \\ University, Columbus, $\mathrm{OH} 43210$, USA \\ ${ }^{2}$ Division of Pharmacy Practice and Administration, College of Pharmacy, The Ohio State \\ University, Columbus, $\mathrm{OH} 43210$, USA \\ ${ }^{3}$ Institute of Ecology and Biological Resources, Vietnam Academy of Science and Technology, \\ Hoang Quoc Viet, Cau Giay, Hanoi, Vietnam
}

${ }^{4}$ Department of Biochemistry and the Virginia Tech Center for Drug Discovery, M/C 0308, Virginia Tech, Blacksburg, VA 24061, USA

${ }^{5}$ Department of Medicinal Chemistry and Pharmacognosy, College of Pharmacy, University of Illinois at Chicago, Chicago, IL 60612, USA

${ }^{6}$ Science and Education, Field Museum of Natural History, 1400 S. Lake Shore Drive, Chicago, IL 60605, USA

\section{Abstract}

Five new lupane triterpene coumaroyl esters (1-5), together with betulin (6) and a known Buxus alkaloid, $N$-3-benzoyldihydrocyclomicrophylline $\mathrm{F}$ (7), were isolated from a $\mathrm{CHCl}_{3}$-soluble partition of a methanol extract of Buxus cochinchinensis Pierre ex Gagnep. (Buxaceae) collected in Vietnam. Isolation work was monitored using human colon cancer cells (HT-29). The structures of the new compounds (1-5) were determined on the basis of spectroscopic data interpretation. In addition to their cytotoxicity against HT-29 cells and NF- $\kappa$ B (p65) inhibitory activity in an ELISA assay, all isolates, as well as two semi-synthetic compounds derived from betulin and $\mathbf{5}$, respectively, were also evaluated for their in vitro antiplasmodial activities against the drugresistant Dd2 strain of Plasmodium falciparum and antifungal effects on the growth of the pathogenic yeast Candida albicans. The new lupane triterpene coumaroyl esters (1-5), along with

\footnotetext{
Corresponding author. Prof. Dr. A. Douglas Kinghorn, Division of Medicinal Chemistry and Pharmacognosy, College of Pharmacy, The Ohio State University, Columbus, OH 43210, USA. kinghorn.4@osu.edu Phone: +1 6142478642 Fax: +1 6142478081

* Dedicated to Professor Dr. Adolf Nahrstedt on the occasion of his $75^{\text {th }}$ birthday

Supporting information

The ${ }^{1} \mathrm{H},{ }^{13} \mathrm{C}$ and $2 \mathrm{D}$ NMR spectra of the new compounds $\mathbf{1 - 5}$, as well as the ${ }^{1} \mathrm{H}$ NMR spectra of two semisynthetic compounds, are available in the Supporting Information.

Conflict of Interest

The authors declare no conflict of interest.
} 
a betulin derivative and the known Buxus alkaloid, were found to show significant in vitro antimalarial activities, with $\mathrm{IC}_{50}$ values ranging from 0.26 to $2.07 \mu \mathrm{M}$.

\section{Keywords}

lupane triterpenes; coumaroyl esters; Buxus cochinchinensis; Buxaceae; cytotoxicity; antimalarial activity

\section{Introduction}

Buxus, commonly known as "boxwood", is the largest genus of the plant family Buxaceae, which comprises over 70 species, and is distributed mainly in southern Europe, southern Asia, Africa, Madagascar, and North and Central America [1]. In addition to being widely used for landscaping purposes, plants of the genus Buxus have also been employed in traditional medicine for the treatment of epilepsy, leprosy, malaria, rheumatism, skin infections, toothache, and venereal disease [2]. Phytochemical studies on plants of the this genus have resulted in the isolation and structural characterization of over 200 Buxus alkaloids, which biosynthetically are considered as degraded triterpenoid alkaloids based on a cycloartenol skeleton. As the major biological active agents from Buxus species, these alkaloids have shown a wide variety of activities, including cytotoxicity, antibacterial, antimalarial, and cholinesterase inhibitory properties [3-5].

Buxus cochinchinensis Pierre ex Gagnep., a large shrub, 1-2 m high, with gray-white stems and dark green fruits, is a boxwood species native to southeastern Asia [6]. To the best of our knowledge, no phytochemical investigation has been carried out on this plant to date. As part of our continuing efforts to discover naturally occurring biologically active agents from plants, a chloroform-soluble partition of a methanol extract from a combination of leaves, twigs and fruits of $B$. cochinchinensis collected in Vietnam was found to show cytotoxicity against the HT-29 human colon cancer line, with an $\mathrm{ED}_{50}$ value of $7.8 \mu \mathrm{g} / \mathrm{mL}$, and thus was fractionated by bioactivity-guided isolation using this assay. Seven lupane-type triterpenes, including five new lupane triterpene coumaroyl esters (1-5), together with two previously known compounds, betulin (6) [7] and $N$-benzoyldihydrocyclomicrophylline F (7) $[8,9]$ were isolated and identified in present study. The structures of the new compounds (1-5) were determined as 3-O-(E)-p-coumaroyl-23-hydroxybetulin (1), 3-O-(E)-p-coumaroyl-23hydroxy-3-epi-betulin (2), 3-O-(Z)-p-coumaroyl-23-hydroxy-3-epi-betulin (3), 23-O-(E)-pcoumaroyl-23-hydroxybetulin (4), and 23-O-(Z)- $p$-coumaroyl-23-hydroxybetulin (5), on the basis of spectroscopic data interpretation.

As mentioned above, plants of the genus Buxus have been reported with antimalarial and antifungal related properties. Thus, besides the human colon cancer cell line HT-29 and the NF- $\kappa B$ inhibitory bioassays, all the isolates obtained in the current study, together with two semi-synthetic compounds, 3,28-O-diacetylbetulin [10] and 23-hydroxybetulin [11], which were derived from betulin and $\mathbf{5}$ respectively, were further screened for their antiplasmodial activities against the drug-resistant Dd2 strain of Plasmodium falciparum and inhibitory effects on the growth of the pathogenic yeast Candida albicans. 


\section{Results and Discussion}

Compounds 1-5 were found to share a common molecular formula of $\mathrm{C}_{39} \mathrm{H}_{56} \mathrm{O}_{5}$ as determined from the sodium adduct ion peak $[\mathrm{M}+\mathrm{Na}]^{+}$in the HRESIMS of each compound. Based on their spectroscopic data interpretation, the structures of compounds 15 could be determined as coumaroyl esters of lupane-type triterpenoid (Fig. 1.), being stereoisomers or positional isomers to each other, as discussed in detail below.

The HRESIMS of 1 afforded a sodiated molecular ion peak at $\mathrm{m} / \mathrm{z} 627.4028$, corresponding to an elemental formula of $\mathrm{C}_{39} \mathrm{H}_{56} \mathrm{O}_{5} \mathrm{Na}$ (calcd for $m / z$ 627.4025). The IR spectrum of compound 1 showed characteristic absorptions of hydroxy group $\left(3400 \mathrm{~cm}^{-1}\right)$ and conjugated ester carbonyl group $\left(1681 \mathrm{~cm}^{-1}\right)$, as well as those for alkene and/or phenyl ring $\left(1604\right.$ and $\left.1514 \mathrm{~cm}^{-1}\right)[12,13]$. The UV absorption maxima at 312 and $227 \mathrm{~nm}$ suggested the presence of a phenolic acid residue [14]. The ${ }^{1} \mathrm{H}$ NMR spectrum displayed signals attributable to a trans-p-coumaroyl group, with an AA'BB' spin system of a 1,4-disubstituted benzene ring at $\delta_{\mathrm{H}} 7.52\left(2 \mathrm{H}, \mathrm{d}, J=8.5 \mathrm{~Hz}, \mathrm{H}-5^{\prime}\right.$ and $\left.9^{\prime}\right)$ and $6.79\left(2 \mathrm{H}, \mathrm{d}, J=8.5 \mathrm{~Hz}, \mathrm{H}-6{ }^{\prime}\right.$ and $\left.8^{\prime}\right)$, as well as a double bond with a trans configuration at $\delta_{\mathrm{H}} 6.32\left(1 \mathrm{H}, \mathrm{d}, J=16.0 \mathrm{~Hz}, \mathrm{H}-2^{\prime}\right)$ and $7.49\left(1 \mathrm{H}, \mathrm{d}, \mathrm{J}=16.0 \mathrm{~Hz}, \mathrm{H}-3^{\prime}\right)$. Also observed in the ${ }^{1} \mathrm{H}$ NMR spectrum were signals of five tertiary methyl groups at $\delta_{\mathrm{H}} 0.72\left(3 \mathrm{H}, \mathrm{s}, \mathrm{H}_{3}-24\right), 0.85\left(3 \mathrm{H}, \mathrm{s}, \mathrm{H}_{3}-25\right), 0.96(3 \mathrm{H}, \mathrm{s}$, $\left.\mathrm{H}_{3}-27\right), 1.10\left(3 \mathrm{H}, \mathrm{s}, \mathrm{H}_{3}-26\right)$, and $1.65\left(3 \mathrm{H}, \mathrm{s}, \mathrm{H}_{3}-30\right)$, while resonances at $\delta_{\mathrm{H}} 4.84(1 \mathrm{H}, \mathrm{dd}, J$ $=11.0$ and $5.0 \mathrm{~Hz}, \mathrm{H}-3$ ), $\delta_{\mathrm{H}} 2.96$ and 3.16 (each $1 \mathrm{H}, \mathrm{d}, J=10.5 \mathrm{~Hz}, \mathrm{H}-23 \mathrm{a}$ and $\mathrm{H}-23 \mathrm{~b}$ ), as well as $\delta_{\mathrm{H}} 3.09$ and 3.53 (each $1 \mathrm{H}, \mathrm{d}, J=10.1 \mathrm{~Hz}, \mathrm{H}-28 \mathrm{a}$ and $\mathrm{H}-28 \mathrm{~b}$ ), were attributed to proton signals attached to an oxygenated methine group and two oxygenated methylene groups, respectively. In addition, the presence of an olefinic methylene was recognized based on the proton resonance at $\delta_{\mathrm{H}} 4.68$ and 4.55 (each1H, brs, H-29a and H-29b) (Table 1). In the ${ }^{13} \mathrm{C}$ NMR spectrum of $\mathbf{1}$, besides the nine carbon resonances ascribed to the $p$ coumaroyl moiety at $\delta_{\mathrm{C}} 166.1$ (C, C-1'), $114.9\left(\mathrm{CH}, \mathrm{C}-2^{\prime}\right), 144.1$ (CH, C-3'), 125.1 (C, C-4'), $130.7\left(2 \times \mathrm{CH}, \mathrm{C}-2^{\prime}\right.$ and $\left.9^{\prime}\right), 115.7\left(2 \times \mathrm{CH}, \mathrm{C}-6^{\prime}\right.$ and $\left.8^{\prime}\right)$ and $159.6\left(\mathrm{C}, \mathrm{C}-7^{\prime}\right)$, the remaining 30 carbon signals were classified from DEPT and HSQC analysis into five methyls, ten alkyl methylenes, five alkyl methines, five alkyl quaternary carbons, three oxygen-bearing carbons (including two primary and one secondary) and two alkene carbons belonging to a disubstituted terminal double bond (Table 2). These NMR data suggested that $\mathbf{1}$ is an $(E)-p$ coumaroyl ester derived from the pentacyclic lupane-type triterpene, with the skeleton similar to those of the known oxygenated betulin analogues [7, 12, 13, 15].In the HMBC spectrum, besides the correlations with $\mathrm{C}-4, \mathrm{C}-23$ and $\mathrm{CH}_{3}-24$, the low-field oxygenated methine proton at $\delta_{\mathrm{H}} 4.84$ was also found to show a key correlation with $\mathrm{C}-1$ ', the carbonyl carbon of the coumaroyl moiety. Consequently, it could be deduced that the esterification by a coumaric acid unit occurs at $\mathrm{C}-3$. Furthermore, the oxygenated methylene protons at $\delta_{\mathrm{H}}$ 2.96 and 3.16, were found to show HMBC correlations with C-5 and C-3, respectively, while signals from another set of oxygenated methylene protons at $\delta_{\mathrm{H}} 3.09$ and 3.53, displayed long range correlations with $\mathrm{C}-16$ and $\mathrm{C}-22$, respectively. Therefore, the positions of the free hydroxy groups were concluded as occurring at C-23 and C-28. In addition, HMBC correlations of the terminal methylene protons of $\mathrm{H}-29$ with $\mathrm{CH}_{3}-30$ and C-19 confirmed the presence of a characteristic isopropene moiety on ring $\mathrm{E}$, which is a typical structural feature of betulin analogues (Fig. 2.). In the NOESY spectrum, key correlation of 
H-3 with H-5, indicated the $\beta$ orientation of the coumaryol substituent on C-3. The NOE effects observed from $\mathrm{H}_{3}-24$ to $\mathrm{H}_{3}-25$, as well as from $\mathrm{H}-23$ to $\mathrm{H}-5$, suggested the hydroxyethylene group (C-23) on C-4 to be an a-position. In the same way, the hydroxyethylene group (C-28) on C-17 was inferred as being $\beta$ oriented based on the NOE resonances of $\mathrm{H}-28 \mathrm{a} / \mathrm{H}-13$ and $\mathrm{H}_{3}-26$. Furthermore, key NOE effects were also observed from $\mathrm{H}_{3}-25$ to $\mathrm{H}_{3}-26, \mathrm{H}_{3}-26$ to $\mathrm{H}-13, \mathrm{H}_{3}-27$ to $\mathrm{H}-9$ and $\mathrm{H}-18$, as well as $\mathrm{H}-19$ to $\mathrm{H}-13$, which revealed that the relative configuration of compound $\mathbf{1}$ is consistent with those of known betulin analogues (Fig. 2.). Accordingly, the structure of $\mathbf{1}$ was elucidated as 3-O(E)-p-coumaroyl-23-hydroxybetulin.

The HRESIMS of compound 2 showed a sodiated molecular ion peak at $\mathrm{m} / z 627.4048$, corresponding to a molecular formula of $\mathrm{C}_{39} \mathrm{H}_{56} \mathrm{O}_{5} \mathrm{Na}$, the same as that of compound $\mathbf{1}$. The NMR spectra of compound $\mathbf{2}$ were quite comparable with that of compound $\mathbf{1}$, with the major differences focused on ring A. In the ${ }^{1} \mathrm{H}$ NMR of $\mathbf{1}, \mathrm{H}-3$ appeared at $\delta_{\mathrm{H}} 4.94$ as a broad singlet, with the coupling pattern very different from that of compound $\mathbf{1}$, where it was observed as a double doublet with coupling constants of 11.0 and $5.0 \mathrm{~Hz}$ (Table 1). This implied that rather than an equatorial $\beta$-position in compound $\mathbf{1}$, the coumaroyl substituent on $\mathrm{C}-3$ in compound 2 adopted an axial a-substitution. Due to this change, a gauche $\gamma$-effect on $\mathrm{C}-1$ of compound $\mathbf{1}$ was caused by the axially oriented coumaroyl group at C-3 [16], which led to an upfield shift of $3.8 \mathrm{ppm}$ for $\mathrm{C}-1$ in the ${ }^{13} \mathrm{C}$ NMR spectrum, when compared with this same signal in compound $\mathbf{1}$ (Table 2). Furthermore, in the NOESY spectrum, H-3 was observed to show strong correlations with $\mathrm{H}-24$ and $\mathrm{H}-2 \beta$, as well as relatively weak correlations with $\mathrm{H}-23$ and $\mathrm{H}-2 \mathrm{a}$, which was consistent with its presumed equatorial $\beta$ configuration. Thus, the structure of compound 2 was elucidated as 3-O-(E)-pcoumaroyl-23-hydroxy-3-epi-betulin (2), or the C-3 epimer of compound $\mathbf{1}$.

The molecular formula of compound $\mathbf{3}$ was determined to be $\mathrm{C}_{39} \mathrm{H}_{56} \mathrm{O}_{5} \mathrm{Na}$, the same as that of compounds 1 and 2 , from the sodiated molecular ion peak at $\mathrm{m} / \mathrm{z} 627.4060$ in the HRESIMS. A close inspection of the NMR data of compounds $\mathbf{2}$ and $\mathbf{3}$ revealed that the major differences were in the coumaroyl residue on C-3. By comparison of the ${ }^{1} \mathrm{H}$ NMR spectrum of $\mathbf{3}$ with that of $\mathbf{2}$, the olefinic doublets of H-2' and H-3' of the coumaroyl group were upfield shifted from $\delta_{\mathrm{H}} 6.33$ and 7.66 to $\delta_{\mathrm{H}} 5.88$ and 6.89 , respectively, with the coupling constant being $\sim 12.7 \mathrm{~Hz}$, smaller than $\sim 16.0 \mathrm{~Hz}$, which was observed for that of compound $\mathbf{2}$ (Table 1). These notable differences suggested that in compound $\mathbf{3}$, the double bond of the $p$-coumaroyl group adopted a $Z$ configuration rather than an $E$ configuration. Further analysis of the 2D NMR of $\mathbf{3}$ revealed the presence of the comparable HMBC effects and NOE correlations with that of compound $\mathbf{2}$. Accordingly, the structure of compound $\mathbf{3}$ was determined as 3-O-(Z)-p-coumaroyl-23-hydroxy-3-epi-betulin (3), a configurational stereoisomer of compound 2 .

Compound 4 gave a molecular formula of $\mathrm{C}_{39} \mathrm{H}_{56} \mathrm{O}_{5}$, the same as that of compounds $\mathbf{1 - 3}$, based on the analysis of the HRESIMS. When the ${ }^{1} \mathrm{H}$ NMR data of compound 4 were compared with those of compound $\mathbf{1}$, the oxygenated methine proton signal assigned to $\mathrm{H}-3$, was shifted upfield from $\delta_{\mathrm{H}} 4.84 \mathrm{ppm}$ to $\delta_{\mathrm{H}} 3.45 \mathrm{ppm}$, while the protons of one oxygenated methylene group appeared at relatively lowfield region with chemical shifts of $\delta_{\mathrm{H}} 3.88(1 \mathrm{H}$, 
$\mathrm{d}, J=11.6 \mathrm{~Hz})$ and $4.38(1 \mathrm{H}, \mathrm{d}, \mathrm{J}=11.6 \mathrm{~Hz})$, respectively (Table 1). In the HMBC spectrum, these two oxygenated methylene protons were observed to have correlations with C-3, C-4, C-24 and the C-1', the carbon of the carbonyl group of the coumaroyl moiety. All this evidence suggested that the esterification with the coumaroyl residue occurred at $\mathrm{C}-23$ in compound 4, instead of on C-3 in compound 1. In addition, the equatorial $\beta$ position of the free hydroxy group on $\mathrm{C}-3$ was concluded from the coupling pattern of $\mathrm{H}-3$ (t, $J=8.0$ $\mathrm{Hz}$ ), and confirmed by the observed NOE correlations of $\mathrm{H}-3$ with $\mathrm{H}-23, \mathrm{H}-1 \mathrm{a}$ as well as $\mathrm{H}-5$. Thus, the structure of compound 4 was elucidated as 23-O-(E)-p-coumaroyl-23hydroxybetulin (4), a positional isomer of compound $\mathbf{1}$.

Compound 5 showed comparable NMR spectra to those of $\mathbf{4}$. The cis configuration of the coumaroyl group was recognized based on the notable upfield shifted olefinic protons (H-2' and $\left.\mathrm{H}^{-} 3^{\prime}\right)$ at $\delta_{\mathrm{H}} 5.84$ and $6.89 \mathrm{ppm}$, as well as a relatively smaller coupling constant of $\sim 12.7$ $\mathrm{Hz}$ ascribed to these two characteristic doublets when compared with compound 4 (Table 1). Further HMBC analysis revealed that the ( $Z$ )- $p$-coumaroyl functionality was also located at C-23, the same as in compound 4. Moreover, key NOE effects observed for 5 were similar to those observed for $\mathbf{4}$. Consequently, compound 5 was designated as 23-O-(Z)- $p$ coumaroyl-23-hydroxybetulin (5), a configurational stereoisomer of compound 4.

Betulin derived lupane-type triterpenes are widely distributed throughout the plant kingdom. A variety of biological activities, including cytotoxicity, antiviral and antibacterial activities, anti-inflammatory activity, and in vitro antimalarial effect, have been ascribed to certain betulin derivatives [17]. The natural occurring of 3-epi-betulin derived triterpenes is much less common than the normal ones, and plant family Celastraceae seems to be one of the major resource containing 3-epi-betulin derivatives [18, 19]. When considering the natural occurring esterification of the hydroxy groups of these betulin-type triterpenes, cinnamon acid derived substitution is not very common and which is more often happened on C-3 and $\mathrm{C}$-28 rather than on other positions of the skeleton. The co-occurrence of $E$ - and $Z$-isomers of the coumaryl moieties in present study may raise the question that if the $E / Z$ isomerization was induced by light in vitro. During the isolation procedure, the purification of these compounds always lasted for several days with the samples exposed to natural light at room temperature, but no notable change has been detected for the ratio of $E / Z$ - coumaryl isomers by HPLC analysis. In addition, for pure compounds $\mathbf{1 - 5}$, which dissolved in deuterium DMSO or $\mathrm{CDCl}_{3}$ and stored in room temperature without light prevention for over 72 hours, no alteration were observed between $E / Z$ - coumaryl isomers. Thus, in present study, the co-occurrence of the $E / Z$-isomers of the coumaryl moieties of the triterpens in Buxus cochinchinensis is more likely derived from a light-independent isomerization, as same as that reported for plants Perrottetia arisanensis and Strychnos vanprukii Craib [18, 20]. All pure compounds obtained in the present investigation were evaluated for their cytotoxic activity against the HT-29 human colon cancer cell line. The known Buxus alkaloid $N$-3-benzoyldihydrocyclomicrophylline F (7) and the new compound, 3- $O$ - $(Z)-p$ coumaroyl-23-hydroxy-3-epi-betulin (3), were found to be the most cytotoxic agents against HT-29 cells in present study, with $\mathrm{ED}_{50}$ values of $1.9 \mu \mathrm{M}$ and $3.3 \mu \mathrm{M}$, respectively. In addition, marginal cytotoxic effects were observed for 3- $O-(E)$ - $p$-coumaroyl-23-hydroxy-3epi-betulin (2) and 23-O-(Z)-p-coumaroyl-23-hydroxybetulin (5). In this bioassay, 
triterpenes with a $(Z)$-p-coumaroyl group exhibited more potent activity than the $(E)-p$ coumaroyl triterpene esters (Table 3).

An ELISA NF- $\kappa$ B assay was also employed to evaluate the p65 (Rel A) inhibitory activity of all the isolates, most of which were considered inactive with their $\mathrm{IC}_{50}$ values of $>20 \mu \mathrm{M}$ in this assay, except for the semi-synthetic compound 23-hydroxybetulin $\left(\mathrm{IC}_{50}=4.0 \mu \mathrm{M}\right)$. This result implied that the occurrence of a free hydroxy group at C-3, C-23 and C-28 in the molecule might be important for the observed NF- $\mathrm{KB}$ inhibitory activity ascribed to 23hydroxybetulin.

Furthermore, the drug-resistant Dd2 strain of Plasmodium falciparum and a pathogenic strain of Candida albicans (ATCC® 18804TM) was used to evaluate the antiplasmodial and antifungal effects of all the isolates, respectively. No obvious growth inhibition of $C$. albicans cells were observed for the test compounds at a concentration of $40 \mu \mathrm{g} / \mathrm{mL}$.

In the $P$. falciparum assay, all the new compounds (1-5), along with the known Buxus alkaloid, $N$-benzoyldihydrocyclomicrophylline $\mathrm{F}(7)$, were found to show significant in vitro antimalarial activities, with $\mathrm{IC}_{50}$ values ranging from 0.26 to $2.07 \mu \mathrm{M}$ (Table 3). To gain some information on the structure-activity relationships, two semi-synthetic compounds, 3,28-O-diacetylbetulin and 23-hydroxybetulin, which were derived from betulin and compound 5 respectively, were also subjected to the same bioassay. The test results showed that 3,28-O-diacetylbetulin, the diacetate derivative of betulin was inactive $\left(\mathrm{IC}_{50}>20 \mu \mathrm{M}\right)$, while 23-hydroxybetulin, the hydrolysis product of compound $\mathbf{5}$, retained antimalarial potency, with an $\mathrm{IC}_{50}$ value of $1.33 \pm 0.37 \mu \mathrm{M}$. Although belutin triterpenes have been reported to possess antimalarial activities, the in vitro tests of these analogues against the parasitic strains to date are not quite significant. According to previously studies, betulinic acid exhibited in vitro antiplasmodial activities against Plasmodium falciparum strains K1, T9-96 and 3D7, with $\mathrm{IC}_{50}$ values ranging from $19.0 \mu \mathrm{M}$ to $56.8 \mu \mathrm{M}$, and its methylate showed in vitro antimalarial activity agains $P$. falciparum strain $3 \mathrm{D} 7$ with an $\mathrm{IC}_{50}$ value of $7.0 \mu \mathrm{m}$ [21-23]. All this evidence suggested that the substitutution of a hydroxy group or a coumaroyl ester group at C-23 plays an important role for the observed antiplasmodial activities ascribed to these betulin derivatives. Moreover, esterification at C-3 or C-23 by coumaroyl group seems to slightly increase the resultant activity, while 3-epi betulin analogues were found be less potent than the normal $3 \beta$ hydroxy derivatives.

Although many Buxus plants have documented ethnomedicinal uses for the treatment of malaria [3, 4], and some plant extracts of in this genus have also been reported to show antimalarial activities in in vitro and/or in vivo studies [24,25], the chemical types of the active principles that are responsible for the antiplasmodial effects are incompletely understood. As the major constituents of boxwood species, Buxus alkaloids have been proposed as the most likely active constituents for the antimalarial activity ascribed to these plants. However, to the best of our knowledge, thus far, only the known cycloartane alkaloid $O$-tigloylcyclovirobuxeine-B, isolated from $B$. sempervirens, has been reported to show in vitro antiplasmodial activity against Plasmodium falciparum, with an $\mathrm{IC}_{50}$ value of $0.92 \mu \mathrm{M}$ $(0.46 \mu \mathrm{g} / \mathrm{mL})$ [26]. The present investigation has revealed that besides the well-known Buxus alkaloids, lupane triterpenoids based on 23-hydroxybetulin, are another class of 
constituents potentially responsible for the antimalarial properties exhibited by plants of the genus Buxus.

\section{Materials and Methods \\ General experimental procedures}

Optical rotations were recorded on a Perkin-Elmer 343 automatic polarimeter

(PerkinElmer). UV spectra were measured on a Hitachi U-2910 spectrophotometer (Hitachi). NMR spectroscopic data were obtained on a Bruker Avance DRX-400 spectrometer (Bruker), using standard Bruker pulse sequences (room temperature), and processed with Topspin ${ }^{\mathrm{TM}} 3.1$ (Bruker BioSpin). High-resolution electrospray ionization mass spectra (HRESIMS) were performed on a Micromass Q-Tof ${ }^{\mathrm{TM}}$ (Micromass) mass spectrometer (calibration with sodium iodide). Analytical TLC was carried out with precoated $250 \mu \mathrm{m}$ thickness silica gel $\mathrm{UV}_{254}$ aluminum-backed plates (Sorbent Technologies), and preparative TLC was carried out with precoated $500 \mu \mathrm{m}$ thickness silica gel UV 254 glass-backed plates (Sorbent Technologies). Column chromatography was conducted on silica gel (230-400 mesh; Sorbent Technologies). The HPLC was carried out on a Waters system comprised of a 600 controller, a 717 Plus autosampler, and a 2487 dual wavelength absorbance detector. Waters Xbridge ${ }^{\circledR}(4.6 \times 150 \mathrm{~mm})$, semi-preparative $(10 \times$ $150 \mathrm{~mm})$, and preparative $(19 \times 150 \mathrm{~mm}) \mathrm{C}_{18}(5 \mu \mathrm{m})$ columns were used for analytical, semi-preparative and preparative HPLC, respectively.

\section{Plant material}

A combination of the leaves, twigs and fruits of Buxus cochinchinensis Pierre ex Gagnep. (Buxaceae) was collected in Nui Chua National Park, Ninh Thuan Province, Vietnam $\left(11^{\circ} 41.128^{\prime} \mathrm{N} ; 109^{\circ} 09.694^{\prime} \mathrm{E}\right)$ by DDS, TNN, and Bui Van Thanh, on $24 \mathrm{July}, 2011$, who also identified this plant. A voucher specimen (original collection Soejarto et al. 14857) has been deposited in the John G. Searle Herbarium of the Field Museum of Natural History (under accession number FM-2300811), Chicago, Illinois.

\section{Extraction and isolation}

A combination of the dried and milled leaves, twigs and fruits of Buxus cochinchinensis (5 $\mathrm{kg}$ ) was macerated overnight using $95 \% \mathrm{MeOH}$ at room temperature $(3 \times 6 \mathrm{~L})$. This crude extract was concentrated under reduced pressure to yield $750 \mathrm{~g}$ of thick dark brown syrup, which was partitioned sequentially with hexane $(3 \times 2 \mathrm{~L})$ and chloroform $(3 \times 2 \mathrm{~L})$. The chloroform partition was washed with $1 \%$ saline solution $(3 \mathrm{~L})$ to yield $150 \mathrm{~g}$ of a partially detannified chloroform-soluble extract, which was found to be active against the HT-29 cell line $\left(\mathrm{ED}_{50}=12.0 \mu \mathrm{g} / \mathrm{mL}\right)$. Accordingly, part of this fraction $(140 \mathrm{~g})$ was subjected to separation over a $\mathrm{Si}$ gel column $(7 \times 50 \mathrm{~cm})$, with a gradient elution system $\mathrm{CH}_{2} \mathrm{Cl}_{2}$-acetone (20:1, 15:1, 10:1, 8:1, 6:1, 4:1, 3:1, 2:1, 1:1 and pure acetone, $4 \mathrm{~L}$ per gradient), to yield 17 fractions (F01-F17). A substantial amount of a white precipitate formed from a non-cytoxic subfraction F03 (15:1, 23.0 g) when it was dissolved in a mixture of $\mathrm{CHCl}_{3}$-methanol (3:1). Betulin (6) (1.0 g, purity > 95\%) was obtained after the recrystallization of this precipitate from the same solvent. Fractions F06 (10:1) and F12 (3:1) were found to be the most active against the HT-29 cells ( $\mathrm{ED}_{50}=8.0$ and $6.3 \mu \mathrm{g} / \mathrm{ml}$, respectively) among these sub-fractions 
obtained. Fraction F06 (2.5 g) was chromatographed over an open $\mathrm{C}_{18}$-reversed phase column $(2 \times 20 \mathrm{~cm})$ with a MeOH$-\mathrm{H}_{2} \mathrm{O}$ gradient solvent system (50:50, 60:40, 70:30, 80:20, and 90:10, $200 \mathrm{~mL}$ per gradient), to yield 17 pooled subfractions (F601- F617).

Subfractions F610 (80:20, $100 \mathrm{mg})$ and F611 (80:20, $110 \mathrm{mg})$ were detected by TLC as terpene-rich subfractions, and were combined and subjected to separation by preparative TLC $(20 \times 20 \mathrm{~cm}, 500 \mu \mathrm{m} \times 2)$, developed by $\mathrm{CHCl}_{3}$-acetone $(5: 1,200 \mathrm{~mL}$ for each plate), to yield compound $4\left(R_{\mathrm{f}}=0.7,12.0 \mathrm{mg}\right.$, purity $\left.>98 \%\right)$, and three subfractions designated as F6(10-11)A-D. Subfraction F6(10-11)C (30 mg) was chromatographed on a semipreparative RP-18 column $(150 \mathrm{~mm} \times 10 \mathrm{~mm}$ i.d. $)$ by $\mathrm{HPLC}$, using a gradient $\mathrm{CH}_{3} \mathrm{CN}-\mathrm{H}_{2} \mathrm{O}$ solvent system [50:50 to $100 \% \mathrm{CH}_{3} \mathrm{CN}$ (both solvent with 0.1 formic acid) in $20 \mathrm{~min}$; flow rate $6.0 \mathrm{~mL} / \mathrm{min}$ ], to afford compound $5\left(15 \mathrm{mg}, t_{R}=11.9 \mathrm{~min}\right.$, purity $\left.>95 \%\right)$. Subfraction F6(10-11)D (33 mg) was purified on the same semi-preparative RP-18 column by HPLC, using a gradient $\mathrm{CH}_{3} \mathrm{CN}-\mathrm{H}_{2} \mathrm{O}$ solvent system [60:40 to $100 \% \mathrm{CH}_{3} \mathrm{CN}$ in $17 \mathrm{~min}$; flow rate $5.0 \mathrm{~mL} / \mathrm{min}$ ], to afford compounds $2\left(6.0 \mathrm{mg}, t_{R}=15.2 \mathrm{~min}\right.$, purity $\left.>95 \%\right)$ and $\mathbf{3}\left(7.0 \mathrm{mg} ; t_{R}\right.$ $=15.8 \mathrm{~min}$, purity $>95 \%)$, respectively. Compound $\mathbf{1}(15 \mathrm{mg}$, purity $>97 \%)$ was precipitated from the parent solution of subfraction F615 (90:10,35 mg) and recrystallized from a mixture of $\mathrm{MeOH}-\mathrm{H}_{2} \mathrm{O}$.

Fraction F12 $(1.2 \mathrm{~g})$ was subjected to passage over a Sephadex LH-20 $(2 \times 35 \mathrm{~cm})$ and eluted with $100 \% \mathrm{MeOH}(600 \mathrm{~mL})$ to furnish five pooled subfractions (F1201- F1205). Subfraction F1204 (200 mg) which gave a positive test for Dragendorff's reagent, was subjected to separation over a Si gel column $(1 \times 40 \mathrm{~cm})$ with gradient elution system $\mathrm{CHCl}_{3}-\mathrm{MeOH}(20: 1,10: 1,5: 1$ and 2:1, $200 \mathrm{~mL}$ per gradient), to afford the known alkaloid $\mathrm{N}$-benzoyldihydrocyclomicrophylline F (7) $(2: 1,5.0 \mathrm{mg})$.

3-O-(E)-p-coumaroyl-23-hydroxybetulin (1): white powder; m.p. $199-200^{\circ} \mathrm{C} ;[\mathrm{a}]^{20}{ }_{\mathrm{D}}+32.0$ (c 0.06, MeOH); UV (MeOH) $\lambda_{\max }(\log \varepsilon) 203$ (4.23), 227 (4.08), 312 (4.34) nm; IR (film) $v_{\max } 3400,2942,2859,1681,1632,1604,1514,1450,1369,1168,1012,831,756 \mathrm{~cm}^{-1} ;{ }^{1} \mathrm{H}$ NMR (400 MHz, DMSO) and ${ }^{13} \mathrm{C}$ NMR (150 MHz, DMSO) data, see Tables 1 and 2; HRESIMS $m / z 627.4028[\mathrm{M}+\mathrm{Na}]^{+}\left(\right.$calcd for $\left.\mathrm{C}_{39} \mathrm{H}_{56} \mathrm{O}_{5} \mathrm{Na}, 627.4025\right)$.

3-O-(E)-p-coumaroyl-23-hydroxy-3-epi-betulin (2): white powder; m.p. $180-182^{\circ} \mathrm{C}$; $[\mathrm{a}]^{20} \mathrm{D}$ +5.0 (c 0.1, MeOH); UV (MeOH) $\lambda_{\max }(\log \varepsilon) 205$ (4.23), 226 (4.10), 312 (4.34) nm; IR (film) $v_{\max } 3350,2945,2854,1681,1631,1604,1514,1450,1368,1167,1025,831,756$ $\mathrm{cm}^{-1} ;{ }^{1} \mathrm{H}$ NMR $\left(400 \mathrm{MHz}, \mathrm{CDCl}_{3}\right)$ and ${ }^{13} \mathrm{C} \mathrm{NMR}\left(150 \mathrm{MHz}, \mathrm{CDCl}_{3}\right)$ data, see Tables 1 and 2; HRESIMS $m / z 627.4048[\mathrm{M}+\mathrm{Na}]^{+}\left(\right.$calcd for $\left.\mathrm{C}_{39} \mathrm{H}_{56} \mathrm{O}_{5} \mathrm{Na}, 627.4025\right)$.

3-O-(Z)-p-coumaroyl-23-hydroxy-3-epi-betulin (3): white powder; m.p. $165-167^{\circ} \mathrm{C}$; [a] ${ }^{20} \mathrm{D}$ -26.5 (c 0.1, MeOH); UV (MeOH) $\lambda_{\max }(\log \varepsilon) 204$ (4.22), 310 (4.19) nm; IR (film) $v_{\max }$ $3352,2944,2859,1688,1604,1514,1451,1376,1167,1026,831,756 \mathrm{~cm}^{-1} ;{ }^{1} \mathrm{H}$ NMR (400 $\left.\mathrm{MHz}, \mathrm{CDCl}_{3}\right)$ and ${ }^{13} \mathrm{C} \mathrm{NMR}\left(150 \mathrm{MHz}, \mathrm{CDCl}_{3}\right)$ data, see Tables 1 and 2; HRESIMS $\mathrm{m} / \mathrm{z}$ $627.4060[\mathrm{M}+\mathrm{Na}]^{+}\left(\right.$calcd for $\left.\mathrm{C}_{39} \mathrm{H}_{56} \mathrm{O}_{5} \mathrm{Na}, 627.4025\right)$.

23-O-(E)-p-coumaroyl-23-hydroxybetulin (4): white powder; m.p. $165-167^{\circ} \mathrm{C} ;[a]^{20} \mathrm{D}+3.0$ (c 0.1, MeOH); UV (MeOH) $\lambda_{\max }(\log \varepsilon) 204$ (4.07), 228 (3.95), 313 (4.24) nm; IR (film) $v_{\max } 3370,2940,2864,1687,1632,1604,1514,1450,1381,1167,1022,831,755 \mathrm{~cm}^{-1} ;{ }^{1} \mathrm{H}$ 
NMR (400 MHz, $\left.\mathrm{CDCl}_{3}\right)$ and ${ }^{13} \mathrm{C} \mathrm{NMR}\left(150 \mathrm{MHz}, \mathrm{CDCl}_{3}\right)$ data, see Tables 1 and 2; HRESIMS $m / z 627.4023[\mathrm{M}+\mathrm{Na}]^{+}\left(\right.$calcd for $\left.\mathrm{C}_{39} \mathrm{H}_{56} \mathrm{O}_{5} \mathrm{Na}, 627.4025\right)$.

23-O-(Z)-p-coumaroyl-23-hydroxybetulin (5): white powder; m.p. $162-163^{\circ} \mathrm{C} ;[\mathrm{a}]^{20} \mathrm{D}+51$ (c 0.1, MeOH); UV (MeOH) $\lambda_{\max }(\log \varepsilon) 204$ (4.10), 311 (4.08) nm; IR (film) $v_{\max } 3374$, 2942, 2870, 1691, 1604, 1514, 1451, 1376, 1166, 1023, 832, $756 \mathrm{~cm}^{-1}$; ${ }^{1} \mathrm{H}$ NMR (400 MHz, $\left.\mathrm{CDCl}_{3}\right)$ and ${ }^{13} \mathrm{C} \mathrm{NMR}\left(150 \mathrm{MHz}, \mathrm{CDCl}_{3}\right.$ ) data, see Tables 1 and 2; HRESIMS $\mathrm{m} / z$ $627.4054[\mathrm{M}+\mathrm{Na}]^{+}\left(\right.$calcd for $\left.\mathrm{C}_{39} \mathrm{H}_{56} \mathrm{O}_{5} \mathrm{Na}, 627.4025\right)$.

\section{Preparation of 3,28-0-diacetylbetulin (8) from betulin (6)}

Betulin $(\mathbf{6})(18 \mathrm{mg})$ was dissolved in a mixture of pyridine $(1.0 \mathrm{~mL})$ and acetic anhydride $(1.0 \mathrm{~mL})$. After being stirred overnight at room temperature, the excess pyridine and acetic anhydride were evaporated to yield nearly $19 \mathrm{mg}$ of 3,28-O-diacetylbetulin (8) (putity > $98 \%$ ). This compound was obtained as white powder [m.p. $222-223^{\circ} \mathrm{C}$ (lit. m.p. $223-$ $224^{\circ} \mathrm{C}$ )], and spectroscopic data (NMR and MS) were consistent with published values [10].

\section{Preparation of 23-hydroxybetulin (9) from 23-O-(Z)-p-coumaroyl-23-hydroxybetulin (5)}

23-O-(Z)-p-coumaroyl-23-hydroxybetulin (5) $(2.0 \mathrm{mg})$ was dissolved in $0.3 \mathrm{~mL} \mathrm{MeOH}$, then $0.3 \mathrm{~mL}$ of $\mathrm{LiOH} \cdot \mathrm{H}_{2} \mathrm{O}\left(5 \mathrm{mg} \mathrm{LiOH}\right.$ dissolved in $0.3 \mathrm{~mL}$ of $\left.\mathrm{H}_{2} \mathrm{O}\right)$ was added. After being stirred overnight at room temperature, $3 \mathrm{~mL}$ of saturated aqueous solution of $\mathrm{NaCl}$ were added to this mixture, and which was further partitioned with $\mathrm{CHCl}_{3}$. The organic phase was evaporated under reduced pressure after washing with water to give 23-hydroxybetulin (9) (1.4 mg, purity > 95\%). This compound was obtained as white powder [m.p. $258-260^{\circ} \mathrm{C}$ (lit. m.p. $260-262^{\circ} \mathrm{C}$ )], and spectroscopic data (NMR and MS) were consistent with published values [11].

\section{Cytotoxicity assay}

The cytotoxic activity of extracts, chromatographic fractions of extracts, and all pure compounds were evaluated against human colon cancer (HT-29) cell line, according to a previously described protocol [27]. Paclitaxel (Sigma-Aldrich, 297\%) was used as positive control substance.

\section{Enzyme-based ELISA NF- $к B$ assay}

The NF- $\kappa$ B p65 subunit inhibitory activity of pure compounds was tested in an ELISA NF$\kappa \mathrm{B}$ assay, which was carried out according to a published protocol [28, 29]. Rocaglamide (Enzo Life Sciences, $297 \%$ ) was used as a positive control substance.

\section{Antimalarial bioassay}

The effects of compounds 1-6 on Plasmodium falciparum Dd2 parasite growth was measured in a $72 \mathrm{~h}$ growth assay, as described previously with minor modifications [30-32]. Artemisinin (Sigma-Aldrich, 98\%) was used as positive control substance. 


\section{Antifungal bioassay}

A pathogenic strain of Candida albicans (ATCC@ 18804 ${ }^{\mathrm{TM}}$ ) was used to evaluate the antifungal effects of all the isolates, according to a published protocol [33]. The antibiotic, amphotericin B (Sigma-Aldrich, 80\%), was used as a positive control substance in this bioassay, which showed $100 \%$ growth inhibition of $C$. albicans cells at a concentration of $0.2 \mathrm{mg} / \mathrm{mL}$.

\section{Supplementary Material}

Refer to Web version on PubMed Central for supplementary material.

\section{Acknowledgment}

This study was supported by grant P01 CA125066 (awarded to A.D. Kinghorn) from NCI, NIH. We are grateful to Dr. Craig McElroy, College of Pharmacy, The Ohio State University, for facilitating the acquisition of the NMR spectroscopic and mass spectrometric data measurements. The plant material was collected under the terms and conditions of a Memorandum of Agreement between the University of Illinois at Chicago and the Institute of Ecology and Biological Resources (IEBR) of the Vietnam Academy of Science and Technology, Hanoi, Vietnam. Thanks are expressed to the Director of Nui Chua National Park for permission, and to the Director of IEBR for overseeing the field operation in the collection of the plant.

\section{References}

1. Batdorf, LR. Boxwood: an Illustrated Encyclopedia. Boyce, VA: American Boxwood Society; 2004. p. 1-343.Hawaii Book Library website, available online at http://www.hawaiilibrary.net/article/ whebn0000334850/buxus [Accessed February 19, 2015]

2. Available on line at https://www.botanical.com/botanical/mgmh/b/box---67.html.

3. Atta-ur-Rahman; Choudhary, MI. Chemistry and biology of steroidal alkaloids. In: Cordell, GA., editor. The Alkaloids. Vol. 50. San Diego: Academic Press; 1998. p. 61-108.

4. Ata A, Andersh BJ. Buxus steroidal alkaloids: chemistry and biology. Alkaloids Chem Biol. 2008; 66:191-213. [PubMed: 19025099]

5. Yan YX, Sun Y, Li ZR, Zhou L, Qiu MH. Chemistry and biological activities of Buxus alkaloids. Curr Bioact Compd. 2011; 7:47-64.

6. Julius A. Buxus holttumiana of Peninsular Malaysia and Thailand is a variety of B. cochinchinensis (Buxaceae). Phyotaxa. 2014; 167:201-204.

7. Mahato SB, Kundu AP. Review article number $98:{ }^{13} \mathrm{C}$ NMR spectra of pentacyclic triterpenoids - a compilation and some salient features. Phytochemistry. 1994; 37:1517-1575.

8. Kupchan SM, Kennedy RM, Schleigh WR, Ohta G. Buxus alkaloids. XII. Benzamide alkaloids from Boxus sempervirens. Tetrahedron. 1967; 23:4563-4586. [PubMed: 6060371]

9. Sangare M, Khuong-Huu F, Herlem D, Millie A, Septe B, Berenger G, Lukacs G. Revision of the configuration of the C-4 hydroxymethylene group in Buxus alkaloids by ${ }^{13} \mathrm{C}$ NMR spectroscopy. Tetrahedron Lett. 1975; 22/23:1791-1794.

10. Symon AV, Veselova NN, Kaplun AP, Vlasenkova NK, Fedorova GA, Lyutik AI, Gerasimova GK, Shvets VI. Synthesis and antitumor activity of cyclopropane derivatives of betulinic and betulonic acids. Russ J Bioorg Chem. 2005; 31:286-291.

11. Dracinsky M, Richtr V, Krecek V, Sejbal J, Klinot J, Budesinsky M. Triterpenes. Part CXIII. Preparation and conformational study of 19ק,28-epoxy-18a-olean-5-ene derivatives. Collect Czech Chem Commun. 2006; 71:387-410.

12. Chang CI, Kou YH. Two new lupane-type triterpenes from Diospyros maritima. J Nat Prod. 1999; 62:309-310. [PubMed: 10075769]

13. Chumkaew P, Kato S, Chantrapromma K. A new triterpenoid ester from the fruits of Bruguiera parviflora. Chem Pharm Bull. 2005; 53:95-96. [PubMed: 15635238] 
14. Robbins RJ. Phenolic acids in foods: an overview of analytical methodology. J Agric. Food Chem. 2003; 51:2866-2887. [PubMed: 12720366]

15. Guerrero-Analco JA, Martineau L, Saleem A, Madiraju P, Muhammad A, Durst T, Haddad P, Arnason JT. Bioassay-guided isolation of the antidiabetic principle from Sorbus decora (Rosaceae) used traditionally by the Eeyou Istchee Cree First Nations. J Nat Prod. 2010; 73:15191523. [PubMed: 20738101]

16. Schneider HJ, Volker H. Carbon-13 nuclear magnetic resonance substituent-induced shieldings and conformational equilibria in cyclohexanes. J Org Chem. 1978; 43:3866-3873.

17. Alakurtti S, Maekelae T, Koskimies S, Yli-Kauhaluoma J. Pharmacological properties of the ubiquitous natural product betulin. Eur J Pharm Sci. 2006; 29:1-13. [PubMed: 16716572]

18. Du YC, Lin AS, Wu CC, Hsieh PW, Chen YH, Chen IH, Chen SL, Yen HF, Lubken T, Chang FR, Wu YC. New cytotoxic lupane triterpenes from Perrottetia arisanensis. Planta Med. 2009; 75:848-855. [PubMed: 19296430]

19. Zhou J, Li CJ, Yang JZ, Ma J, Li Y, Bao XQ, Chen XG, Zhang D, Zhang DM. Lupane triterpenoids from the stems of Euonymus carnosus. J Nat Prod. 2014; 77:276-284. [PubMed: 24467317]

20. Chien NQ, Hung NV, Santarsiero BD, Mesecar AD, Cuong NM, Soejarto DD, Pezzuto JM, Fong HHS, Tan GT. New 3-O-acyl betulinic acids from Strychnos vanprukii Craib. J Nat Prod. 2004; 67:994-998. [PubMed: 15217281]

21. Steele JCP, Warhurst DC, Kirby GC, Simmonds MSJ. In vitro and in vivo evaluation of betulinic acid as an antimalarial. Phytother Res. 1999; 13:115-119. [PubMed: 10190183]

22. Ziegler HL, Franzyk H, Sairafianpour M, Tabatabai M, Tehrani MD, Bagherzadeh K, Hagerstrand H, Staerk D, Jaroszewski JW. Erythrocyte membrane modifying agents and the inhibition of Plasmodium falciparum growth: structure-activity relationships for betulinic acid analogues. Bioorg Med Chem. 2004; 12:119-127. [PubMed: 14697777]

23. Duker-Eshun G, Jaroszewski JW, Asomaning WA, Oppong-Boachie F, Christensen SB. Antiplasmodial constituents of Cajanus cajan. Phytother Res. 2004; 18:128-130. [PubMed: 15022164]

24. Esmaeili S, Naghibi F, Mosaddegh M, Sahranavard S, Ghafari S, Abdullah NR. Screening of antiplasmodial properties among some traditionally used Iranian plants. J Ethnopharmcol. 2009; 121:400-404.

25. Orhan IE, Erdem SA, Senol FS, Kartal M, Sener B. Exploration of cholinesterase and tyrosinase inhibitory, antiprotozoal and antioxidant effects of Buxus sempervirens L. (boxwood). Ind Crops Prod. 2012; 40:116-121.

26. Althaus J, Jerz G, Winterhalter P, Kaiser M, Brun R, Schmidt TJ. Antiprotozoal activity of Buxus sempervirens and activity-guided isolation of $O$-tigloylcyclovirobuxeine-B as the main constituent active against Plasmodium falciparum. Molecules. 2014; 19:6184-6201. [PubMed: 24838073]

27. Pan L, Kardono LBS, Riswan S, Chai HB, Carcache de Blanco EJ, Pannell CM, Soejarto DD, McCloud TG, Newman DJ, Kinghorn AD. Isolation and characterization of minor analogues of silvestrol and other constituents from a large-scale recollection of Aglaia foveolata. J. Nat. Prod. 2010; 73:1873-1878. [PubMed: 20939540]

28. Renard P, Ernest I, Houbion A, Art M, Le Calvez H, Raes M, Remacle J. Development of a sensitive multi-well colorimetric assay for active NFк:B. Nucleic Acids Res. 2001; 29:e21. [PubMed: 11160941]

29. Deng Y, Balunas MJ, Kim JA, Lantvit DD, Chin YW, Chai HB, Sugiarso S, Kardono LBS, Fong HHS, Pezzuto JM, Swanson SM, Carcache-Blanco EJ, Kinghorn AD. Bioactive 5,6-dihydroalpha-pyrone derivatives from Hyptis brevipes. J Nat Prod. 2009; 72:1165-1169. [PubMed: 19422206]

30. Smilkstein M, Sriwilaijaroen N, Kelly JX, Wilairat P, Riscoe M. Simple and inexpensive fluorescence-based technique for high-throughput antimalarial drug screening. Antimicrob Agents Chemother. 2004; 48:1803-1806. [PubMed: 15105138]

31. Bennett TN, Paguio M, Gligorijevic B, Seudieu C, Kosar AD, Davidson E, Roepe PD. Novel, rapid, and inexpensive cell-based quantification of antimalarial drug efficacy. Antimicrob Agents Chemother. 2004; 48:1807-1810. [PubMed: 15105139] 
32. Dai Y, Harinantenaina L, Bowman JD, Da Fonseca IO, Brodie PJ, Goetz M, Cassera MB, Kingston DGI. Isolation of antiplasmodial anthraquinones from Kniphofia ensifolia and synthesis and structure-activity relationships of related compounds. Bioorg Med Chem. 2014; 22:269-276. [PubMed: 24326280]

33. National Committee for Clinical Laboratory Standards. Reference Method for Broth Dilution Antifungal Susceptibility Testing of Yeasts: Approved Standard. Vol. 17. Wayne, PA: NCCLS document M27-A; 1997. p. 1-29. 


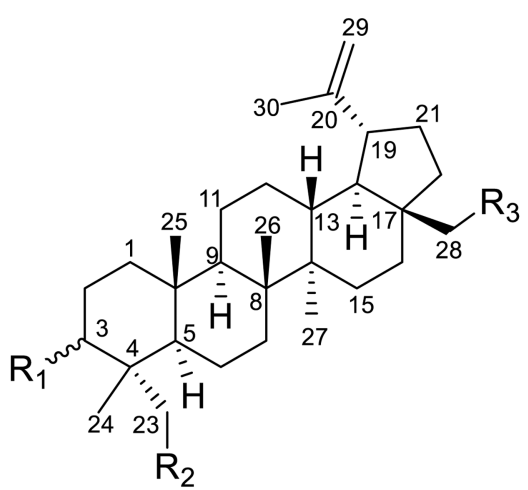

1

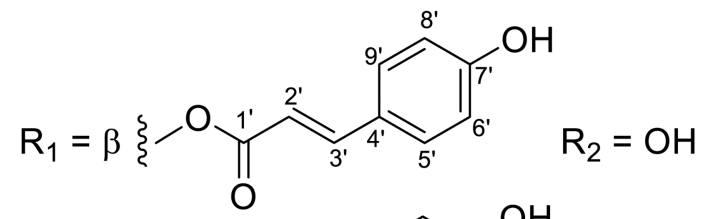

2<smiles>[R][R]=[R]OC(=O)/C=C\c1ccc(Cl)cc1</smiles>

$4 \quad \mathrm{R}_{1}=\beta-\mathrm{OH}$

$5 \quad \mathrm{R}_{1}=\beta-\mathrm{OH}$

$6 \quad \mathrm{R}_{1}=\beta-\mathrm{OH}$

$8 \quad \mathrm{R}_{1}=\beta-\mathrm{OAc}$

$9 \quad \mathrm{R}_{1}=\beta-\mathrm{OH}$

$\mathrm{R}_{2}=\mathrm{OH}$

$\mathrm{R}_{2}=\mathrm{H}$

$\mathrm{R}_{2}=\mathrm{H}$

$\mathrm{R}_{2}=\mathrm{OH}$<smiles>[R][R]#[13C]OC(=O)/C=C/C(C)=C/C=C\C</smiles>

Fig. 1.

Chemical structures of new compounds 1-9.

$\mathrm{R}_{3}=\mathrm{OH}$

$\mathrm{R}_{3}=\mathrm{OAC}$

$\mathrm{R}_{3}=\mathrm{OH}$

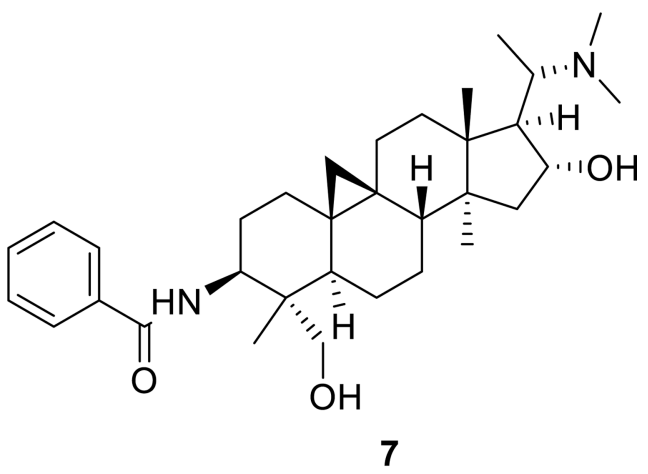

$\mathrm{R}_{3}=\mathrm{OH}$

$\mathrm{R}_{3}=\mathrm{OH}$ 


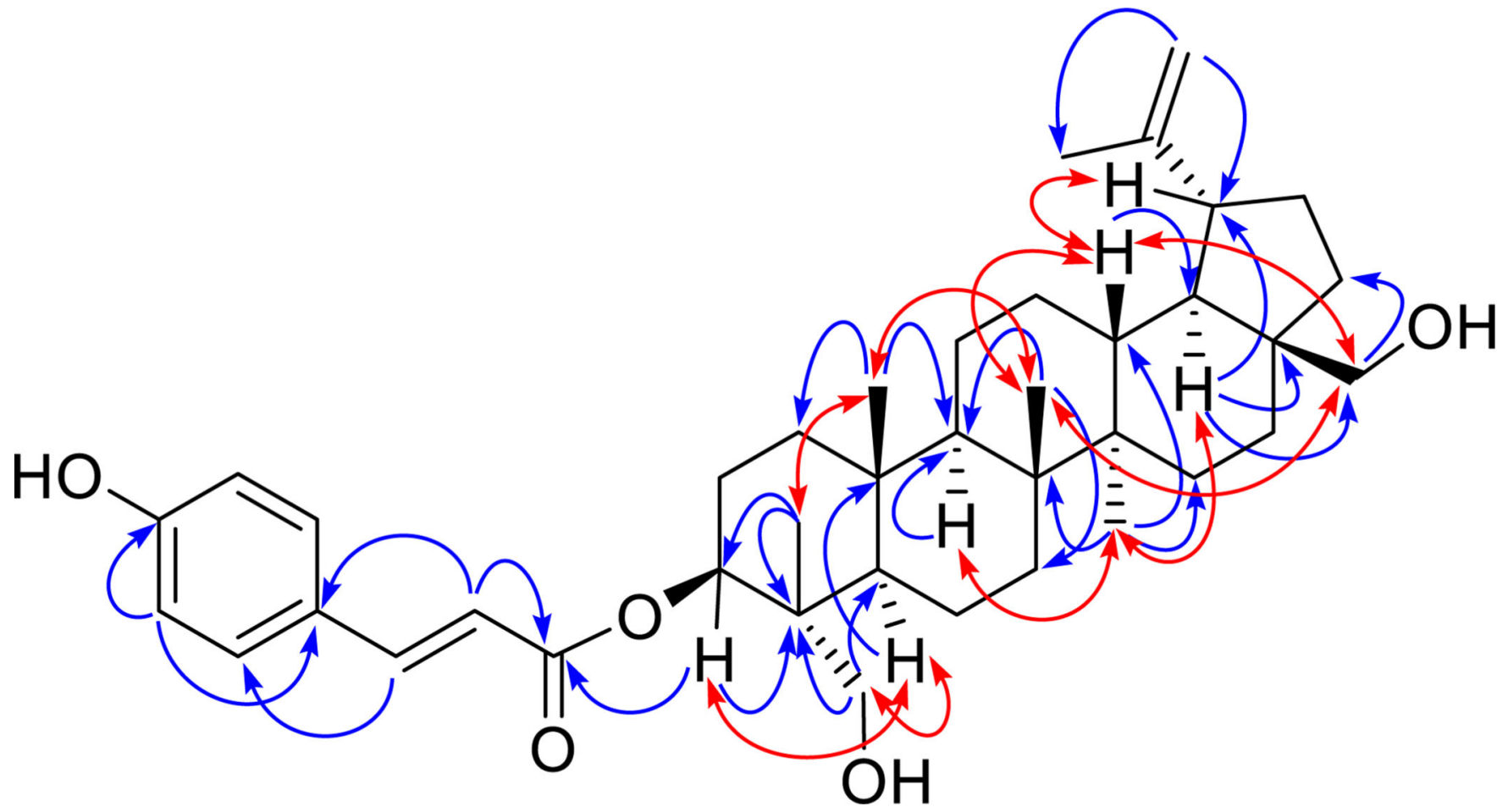

Fig. 2.

Selected HMBC $(\rightarrow)$ and NOESY $(\leftrightarrow)$ correlations observed for compound $\mathbf{1}$. 
Table 1

${ }^{1} \mathrm{H}$ NMR Chemical Shifts of Compounds $\mathbf{1 - \mathbf { 5 } ^ { a }}$

\begin{tabular}{|c|c|c|c|c|c|}
\hline Position & 1 & 2 & 3 & 4 & 5 \\
\hline $1 a$ & $0.91, \mathrm{~m}$ & $1.21^{b}$ & $1.34^{b}$ & $0.93, \mathrm{~m}$ & $0.85, \mathrm{~m}$ \\
\hline $1 \beta$ & $1.61^{b}$ & $1.48^{b}$ & $1.44^{b}$ & $1.69^{b}$ & $1.65^{b}$ \\
\hline $2 a$ & $1.61^{b}$ & $1.92^{b}$ & $1.90^{b}$ & $1.67^{b}$ & $1.63^{b}$ \\
\hline $2 \beta$ & $1.68^{b}$ & $1.69^{b}$ & $1.67^{b}$ & $1.67^{b}$ & $1.63^{b}$ \\
\hline 3 & $4.84, \mathrm{dd}(11.0,5.0)$ & $4.94, \mathrm{~s}$ & $4.85, \mathrm{~s}$ & $3.45, \mathrm{t}(8.0)$ & $3.35^{b}$ \\
\hline 5 & $1.27^{b}$ & $1.37^{b}$ & $1.29^{b}$ & $1.03^{b}$ & $0.91^{b}$ \\
\hline $6 a$ & $1.45^{b}$ & $1.46^{b}$ & $1.41^{b}$ & $1.49^{b}$ & $1.39^{b}$ \\
\hline $6 \beta$ & $1.31^{b}$ & $1.30^{b}$ & $1.29^{b}$ & $1.43^{b}$ & $1.39^{b}$ \\
\hline $7 \mathrm{a}$ & $1.31^{b}$ & $1.39^{b}$ & $1.34^{b}$ & $1.43^{b}$ & $1.31^{b}$ \\
\hline $7 \mathrm{~b}$ & $1.49^{b}$ & $1.48^{b}$ & $1.44^{b}$ & $1.43^{b}$ & $1.31^{b}$ \\
\hline 9 & $1.35^{b}$ & $1.46^{b}$ & $1.38^{b}$ & $1.32^{b}$ & $1.25^{b}$ \\
\hline $11 \mathrm{a}$ & $1.38^{b}$ & $1.46^{b}$ & $1.44^{b}$ & $1.42^{b}$ & $1.39^{b}$ \\
\hline $11 b$ & $1.19^{b}$ & $1.22^{b}$ & $1.20^{b}$ & $1.21^{b}$ & $1.20^{b}$ \\
\hline $12 a$ & $1.04^{b}$ & $1.11^{b}$ & $1.10^{b}$ & $1.05^{b}$ & $1.04^{b}$ \\
\hline $12 \beta$ & $1.59^{b}$ & $1.66^{b}$ & $1.65^{b}$ & $1.65^{b}$ & $1.63^{b}$ \\
\hline 13 & $1.59^{b}$ & $1.64^{b}$ & $1.63^{b}$ & $1.65^{b}$ & $1.62^{b}$ \\
\hline $15 \mathrm{a}$ & $1.69^{b}$ & $1.71^{b}$ & $1.71^{b}$ & $1.70^{b}$ & $1.68^{b}$ \\
\hline $15 b$ & $0.91^{b}$ & $1.08^{b}$ & $1.05^{b}$ & $1.08^{b}$ & $1.04^{b}$ \\
\hline $16 \mathrm{a}$ & $1.93^{b}$ & $1.93^{b}$ & $1.94^{b}$ & $1.94^{b}$ & $1.94^{b}$ \\
\hline $16 b$ & $1.10^{b}$ & $1.24^{b}$ & $1.22^{b}$ & $1.22^{b}$ & $1.21^{b}$ \\
\hline 18 & $1.50^{b}$ & $1.60^{b}$ & $1.60^{b}$ & $1.57^{b}$ & $1.57^{b}$ \\
\hline 19 & $2.39, \mathrm{~m}$ & $2.40, \mathrm{~m}$ & $2.39, \mathrm{~m}$ & $2.38, \operatorname{td}(10.0,5.8)$ & $2.38, \operatorname{td}(10.3,5.7)$ \\
\hline $21 a$ & $1.28^{b}$ & $1.41^{b}$ & $1.41^{b}$ & $1.41^{b}$ & $1.41^{b}$ \\
\hline $21 \beta$ & $1.87^{b}$ & $1.96^{b}$ & $1.94^{b}$ & $1.94^{b}$ & $1.94^{b}$ \\
\hline $22 a$ & $0.88^{b}$ & $1.06^{b}$ & $1.05^{b}$ & $1.05^{b}$ & $1.05^{b}$ \\
\hline $22 \beta$ & $1.87^{b}$ & $1.88^{b}$ & $1.86^{b}$ & $1.86^{b}$ & $1.86^{b}$ \\
\hline $23 \mathrm{a}$ & $2.96, \mathrm{~d},(10.5)$ & $3.34^{b}$ & $3.35^{b}$ & $3.88, \mathrm{~d},(11.6)$ & $3.83, \mathrm{~d},(12.2)$ \\
\hline $23 b$ & $3.16, \mathrm{~d},(10.5)$ & $3.40, \mathrm{~d},(11.2)$ & $3.35^{b}$ & $4.38, \mathrm{~d},(11.6)$ & $4.28, \mathrm{~d},(11.4)$ \\
\hline 24 & $0.72, \mathrm{~s}$ & $0.95, \mathrm{~s}$ & $0.92, \mathrm{~s}$ & $0.81, \mathrm{~s}$ & $0.76, \mathrm{~s}$ \\
\hline 25 & $0.85, \mathrm{~s}$ & $0.92, \mathrm{~s}$ & $0.89, \mathrm{~s}$ & $0.87, \mathrm{~s}$ & $0.84, \mathrm{~s}$ \\
\hline 26 & $1.10, \mathrm{~s}$ & $1.05^{b}$ & $1.02^{b}$ & $1.03, \mathrm{~s}$ & $1.00, \mathrm{~s}$ \\
\hline 27 & $0.96, \mathrm{~s}$ & $1.05^{b}$ & $1.03^{b}$ & $0.98, \mathrm{~s}$ & $0.93, \mathrm{~s}$ \\
\hline $28 \mathrm{a}$ & $3.09, \mathrm{~d},(10.1)$ & $3.34^{b}$ & $3.35^{b}$ & $3.34, \mathrm{~d},(10.9)$ & $3.34^{b}$ \\
\hline $28 \mathrm{~b}$ & $3.53, \mathrm{~d},(10.1)$ & $3.82, \mathrm{~d},(10.3)$ & $3.82, \mathrm{~d},(10.3)$ & $3.80, \mathrm{~d},(10.9)$ & $3.80, \mathrm{~d},(11.2)$ \\
\hline
\end{tabular}

Planta Med. Author manuscript; available in PMC 2016 August 01. 


\begin{tabular}{llllll}
\hline Position & $\mathbf{1}$ & $\mathbf{2}$ & $\mathbf{3}$ & $\mathbf{4}$ & $\mathbf{5}$ \\
\hline $29 \mathrm{a}$ & $4.68, \mathrm{brs}$ & $4.70, \mathrm{brs}$ & $4.70, \mathrm{brs}$ & $4.68, \mathrm{brs}$ & $4.67, \mathrm{brs}$ \\
$29 \mathrm{~b}$ & $4.55, \mathrm{brs}$ & $4.59, \mathrm{brs}$ & $4.59, \mathrm{brs}$ & $4.57, \mathrm{brs}$ & $4.58, \mathrm{brs}$ \\
30 & $1.65, \mathrm{~s}$ & $1.69, \mathrm{~s}$ & $1.70, \mathrm{~s}$ & $1.67, \mathrm{~s}$ & $1.68, \mathrm{~s}$ \\
Coumaric acid & & & & & \\
$1^{\prime}$ & & & & & \\
$2^{\prime}$ & $6.32, \mathrm{~d},(16.0)$ & $6.33, \mathrm{~d},(15.9)$ & $5.88, \mathrm{~d},(12.6)$ & $6.27, \mathrm{~d},(15.9)$ & $5.84, \mathrm{~d},(12.6)$ \\
$3^{\prime}$ & $7.49, \mathrm{~d},(16.0)$ & $7.66, \mathrm{~d},(15.8)$ & $6.89, \mathrm{~d},(12.8)$ & $7.63, \mathrm{~d},(15.9)$ & $6.89, \mathrm{~d},(12.7)$ \\
$5^{\prime}, 9^{\prime}$ & $7.52(8.5)$ & $7.44(8.5)$ & $7.64(8.5)$ & $7.41(8.6)$ & $7.61(8.4)$ \\
$6^{\prime}, 8^{\prime}$ & $6.79, \mathrm{~d},(8.5)$ & $6.84, \mathrm{~d},(8.5)$ & $6.79, \mathrm{~d},(8.6)$ & $6.83, \mathrm{~d},(8.6)$ & $6.80, \mathrm{~d},(8.6)$ \\
\hline
\end{tabular}

${ }^{a}$ Measured at $400 \mathrm{MHz}$; NMR data of compound $\mathbf{1}$ was obtained in DMSO- $d_{6}$; NMR data of compounds 2-5 were obtained in $\mathrm{CDCl}_{3}$ with TMS as internal standard; $J$ values $(\mathrm{Hz})$ are given in parentheses. Assignments are based on ${ }^{1} \mathrm{H}_{-}{ }^{1} \mathrm{H}$ COSY, HSQC, and $\mathrm{HMBC}$ spectroscopic data.

${ }^{b}$ Multiplicity patterns unclear due to signal overlapping. 


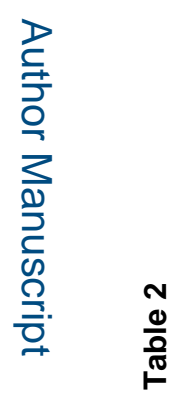




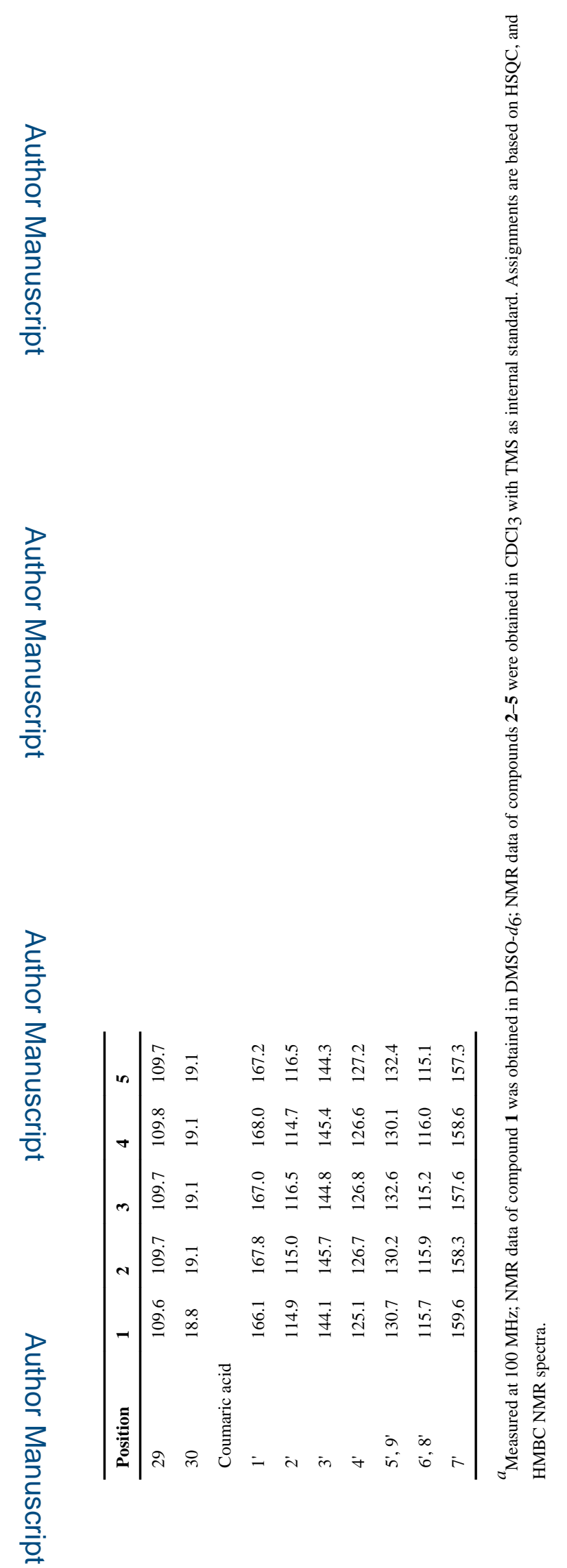

Planta Med. Author manuscript; available in PMC 2016 August 01. 
Table 3

Bioactivity evaluation of compounds isolated from B. cochinchinensis. ${ }^{a, b}$

\begin{tabular}{llll}
\hline Compound & HT-29 $^{c}$ & NF-kB (p65) & P. falciparum $^{\boldsymbol{e}}$ \\
$\mathbf{1}$ & $>20$ & $>20$ & $0.65 \pm 0.06$ \\
$\mathbf{2}$ & 13.2 & $>20$ & $1.28 \pm 0.13$ \\
$\mathbf{3}$ & 3.3 & $>20$ & $1.02 \pm 0.09$ \\
$\mathbf{4}$ & $>20$ & $>20$ & $0.26 \pm 0.01$ \\
$\mathbf{5}$ & 18.4 & $>20$ & $0.63 \pm 0.02$ \\
$\mathbf{6}$ & $>20$ & $>20$ & $>10$ \\
$\mathbf{7}$ & 1.9 & $>20$ & $2.07 \pm 0.13$ \\
$\mathbf{8}$ & $>20$ & $>20$ & $>10$ \\
$\mathbf{9}$ & $>20$ & 4.0 & $1.33 \pm 0.37$ \\
Paclitaxef $f$ & 0.001 & - & - \\
Rocaglamide $g$ & - & 0.08 & - \\
Artemisinin $^{h}$ & - & - & 0.0007 \\
\hline
\end{tabular}

${ }^{a}$ No obvious growth inhibition of $C$. albicans cells were observed for the test compounds at a concentration of $40 \mathrm{mg} / \mathrm{mL}$.

${ }^{b}$ Results are expressed as $\mathrm{ED}_{50}$ or IC 50 values $(\mu \mathrm{M})$.

${ }^{c}$ Compounds with ED50 values of $>20 \mu \mathrm{M}$ in HT-29 cells are considered inactive.

${ }^{d}$ Compounds with IC50 values of $>20 \mu \mathrm{M}$ on an enzyme-based ELISA NF- $\kappa \mathrm{B}$ (p65) assay are considered inactive.

${ }^{e}$ Compounds with IC50 values of $>10 \mu \mathrm{M}$ in $P$. falciparum assay are considered inactive.

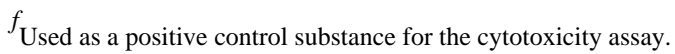

${ }^{g}$ Used as a positive control substance for the cytotoxicity assay.

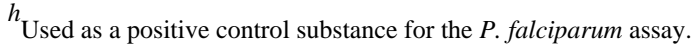

